\section{Notas para uma aproximação entre o neodarwinismo e as ciências sociais}

\author{
Notes on an \\ approximation between \\ neo-Darwinism and the \\ social sciences
}

WAIZBORT, R.: Notas para uma aproximação entre o neodarwinismo e as ciências sociais. História, Ciências, Saúde - Manguinhos, v. 12, n. 2, p. 293-318, maio-ago. 2005.

O objetivo deste trabalho é apresentar a psicologia evolutiva, uma ciência que procura compreender a mente humana (cultural, social, histórica) como produto de processos biológicos e evolutivos, e a memética, uma teoria ainda incipiente que pretende tratar a informação cultural e as próprias tradições como complexos de idéias, que usam os cérebros humanos para se reproduzirem. Essas duas novas abordagens pretendem contribuir para integrar as ciências biológicas e as ciências sociais.

PALAVRAS-CHAVE: neodarwinismo; psicologia evolutiva; memética; ciências sociais; ciências naturais.

WAIZBORT, R.: Notes on an approximation between neo-Darwinism and the social sciences.

História, Ciências, Saúde - Manguinhos, v. 12, n. 2, p. 293-318, May-Aug. 2005.

Evolutionary psychology is a science that endeavors to understand the human mind (cultural, social, historical) as a product of biological and evolutionary processes. Memetics is an incipient theory that views cultural information and traditions as sets of ideas that reproduce themselves within the human brain. The article introduces these two new approaches and explores how they intend to contribute to the integration of the biological and social sciences.

KEYWORDS: neo-Darwinism; evolutionary psychology; memetics; social sciences; natural sciences.
Ricardo Waizbort

Pesquisador da Casa de Oswaldo Cruz Av. Brasil 4365 Prédio do Relógio, Manguinhos 21040-900 Rio de Janeiro - RJ Brasil

ricw@coc.fiocruz.br 


\section{Introdução}

A s últimas duas décadas do século XX assistiram a um fenômeno social que promete se prolongar ainda por muito tempo em toda sua profundidade. Embora os primeiros signos desse acontecimento tenham sido tão radicais que provocaram imediatas reações contrárias, aos poucos vai se elaborando uma linguagem amplamente matizada, embora não menos contundente e controvertida, que começa a dar voz à tentativa de integrar estudos biológicos e sociológicos. Segundo alguns autores trata-se de uma darwinização da sociologia (Runcinam, 1998). Talvez um sinal evidente desse movimento esteja, por exemplo, na permeabilidade de instituições de renome, como a Revista Brasileira de Ciências Sociais ou a revista Dados, em publicar artigos como os de Freitas (2000), ou o de Leis (2000), nos quais aparece a clara intenção de trazer para o diálogo os pensamentos social e biológico.

Tendo sido depurada de más interpretações como o darwinismo social e um sem-número de mal-entendidos, tais como o lamarckismo e o mutacionismo (Bowler, 1989; Mayr, 1998), a Teoria Sintética da Evolução alcançou, no final da década de 1940, uma sólida sustentação em rigorosas bases darwinistas. Isso significa que, passados hoje mais de cento e quarenta anos da publicação de Origem das espécies, a ortodoxia dentro da biologia continua crendo basicamente que Darwin estava certo: o processo pelo qual as espécies de seres vivos se diversificam é o da descendência com modificação submetida continuamente às pressões ambientais da seleção natural (Darwin, 1985). A teoria da evolução de Darwin envolve um processo de dois tempos: em primeiro lugar deve haver uma base de traços fenotípicos variáveis em uma população; apenas conseqüentemente sobre essas diferenças é que alguma seleção pode ocorrer (Mayr, 1998). Sem variações não pode haver seleção.

A descoberta da base material e física da hereditariedade, que começou com as ervilhas de Mendel e alcançou a maioridade a partir dos modelos de arame e química de Watson e Crick em 1953, ${ }^{1}$ ofereceu ao darwinismo suporte teórico-conceitual e corroborações empíricas inimagináveis. ${ }^{2}$ Entretanto, o darwinismo clássico e a Teoria Sintética da Evolução diferem em pontos importantes. Por exemplo: a teoria de Darwin, Wallace, Huxley, Lyell, Hooker, entre outros ressalta mais os benefícios que as adaptações trazem do que seus custos (Cronin, 1995). O neodarwinismo atual, que é uma das bases teóricas da psicologia evolutiva, saberia equilibrar mais a relação entre benefícios e custos das adaptações. Tal reformulação estaria radicada na chamada Teoria Sintética da Evolução, a síntese entre o pensamento populacional de Darwin e a concepção particularista de herança de Mendel. Pode-se dizer então que a psicologia evolutiva faz parte de um florescente programa de pesquisa 
que promoveu a síntese entre o darwinismo selecionista e o mendelismo genético. Tal modelo explicativo seria aplicável não só a domínios meramente biológicos, mas também a campos antes delimitados aos estudos da sociedade, da história e da cultura (Dennett, 1998).

A proposta deste trabalho não é apresentar de um modo sistemático essa 'invasão' da biologia a domínios sociais e culturais, mas delinear duas fortes tendências que foram originadas no contexto da biologia evolutiva. Por um lado temos a psicologia evolutiva, herdeira atual da controvertida sociobiologia. A psicologia evolutiva procura compreender a mente humana (cultural, social, histórica) como um produto de forças evolutivas que foram modificadas largamente, mas não anuladas, pela evolução das sociedades urbanas modernas. Exatamente por sua ambição de investigar o comportamento social dos animais humanos é que a psicologia evolutiva difere da sociobiologia, uma vez que esta última procurava investigar o comportamento social de animais não humanos. Mas temos, também, o programa de pesquisa dos memes, uma investigação ainda incipiente que pretende tratar a informação cultural e as próprias tradições como complexos de idéias, de memes, que usam os cérebros humanos para se reproduzirem.

Embora a abrangência do assunto por si só pudesse justificar a falência no tratamento sistemático do tema, a fragmentação com que trabalharei a seguir busca abrir lacunas para que o leitor interessado as preencha. Nesse sentido, o presente trabalho pode ser interpretado como uma espécie de trilha bibliográfica não obrigatória e não exaustiva que, no entanto, tem a pretensão de conduzir ao debate sobre a integração das ciências sociais com as biológicas.

\section{A psicologia evolutiva}

Ainda é comum considerar que há um fosso intransponível entre as ciências naturais e as ciências sociais. Esse abismo já foi interpretado como uma extensão do famoso 'problema das duas culturas'. Na década de 1950 Charles Percy Snow, um bioquímico que abandonou sua profissão para se tornar escritor e critico literário, escreveu um livro, justamente chamado As duas culturas, assinalando o fosso aparentemente intransponível entre ciências físicas de um lado, e os estudiosos das humanidades do outro (Snow, 1995). A popularização da doutrina conhecida como 'sociobiologia', fundada em meados da década de 1970, talvez tenha contribuído para ampliar a sensação de ruptura entre os discursos social e natural, na medida em que almejava reduzir a cultura e a sociedade, em última instância, a subprodutos ou epifenômenos da evolução dos genes (Blackmore, 1999, p. 32-6; Ruse, 1983). Apesar da má impressão que possa ter causado a sociobiologia, parece-me, acima 
de qualquer dúvida, razoável a versão científica hegemônica acerca dos fenômenos da origem e evolução da vida como um processo no qual desempenham um papel fundamental a hereditariedade (os genes), a variação (a mutação) e a seleção natural (e, no caso do Homo sapiens, também a seleção artificial). Nesse cenário, os genes são considerados como replicadores biológicos, estruturas físicas que possuem informações químicas que são reproduzidas a cada geração, além de conterem informações para a síntese de proteínas. Os genes são replicadores biológicos que possuem o código químico pelo qual a vida se reproduz por bilhões de anos.

Ocorre que as forças seletivas que fizeram o Homo sapiens emergir, e nos fazem o que somos hoje, foram enormemente modificadas pelo advento das formas humanas - sociais, culturais, filosóficas, artísticas, científicas, tecnológicas, políticas - de lidar com o meio ambiente. Independentemente da definição que dermos ao ser humano podese dizer que a forma atual (Homo sapiens sapiens) começou a emergir há duzentos ou cem mil anos, embora um homem tal qual nós hoje reconheceríamos como um igual só tivesse emergido há quarenta mil anos. Embora essas cifras possam parecer grandiosas para um historiador, por exemplo, elas representam uma pequena fração da história dos hominídeos, e uma parcela ainda mais ínfima da história dos mamíferos, e muito, muito menor ainda da história da vida como um todo. Todas essas histórias têm sido reconstruídas a partir de investigações empíricas metodolo-gicamente rigorosas, sejam elas no campo da geologia, da paleontologia, da paleoantropologia ou da arqueologia. Ainda assim, a evolução do homem, especialmente a encefalização (processo que levou ao crescimento do cérebro), é um fenômeno que ainda intriga bastante os cientistas. A abordagem típica da evolução sustenta que os humanos surgiram a partir de um ancestral comum que compartilhamos com os chimpanzés, entre cinco e seis milhões de anos atrás na África oriental. Isso a respeito das origens da família hominídea. Quanto à aparição dos primeiros Homo sapiens há também controvérsias importantes, assim como a respeito das possíveis relações entre o Homo sapiens e o Homo neandertalis. Também são controversas as relações filogenéticas entre o Homo habilis e o Homo erectus. O que se sabe é que a história evolutiva da família hominídea não foi em absoluto linear. Houve muito mais do que uma espécie do gênero Homo, e muitas delas provavelmente se extinguiram, não contribuindo em nada para a emergência do Homo sapiens. Assim também foram encontrados fósseis de diferentes espécies de Australopitecus, embora existam controvérsias envolvendo a consideração de espécies desse gênero como ancestrais da espécie Homo sapiens. $^{3}$

A partir da revolução agrícola, ocorrida em torno de dez mil anos atrás, as pressões seletivas começaram a ser profundamente modificadas, de forma que os seres humanos, sobretudo nas socieda- 
des ocidentalizadas, não estão mais impostos aos limites naturais de recursos (Diamond, 2001). O aparecimento das sociedades hierarquizadas, da divisão de trabalho, das máquinas e das indústrias, permite que o homem crie o ambiente no qual vai viver. Essas circunstâncias históricas transformaram tanto o ambiente humano, que muitos pensadores crêem haver uma ruptura insuperável entre os dois mundos, o da natureza e o da cultura, cada um deles requerendo seus próprios métodos.

Ao contrário da sociobiologia - que só indiretamente tratava do comportamento social humano, buscando demonstrar as bases biológicas da ação de outros animais sociais (Wilson, 1975; Ruse, 1983) -, a psicologia evolutiva procura entender a mente a partir do enraizamento humano no mundo vivo. Tratando o Homo sapiens como produto de processos genéticos e seletivos que ocorrem na natureza, a psicologia evolutiva procura demonstrar um iniludível componente biológico no comportamento do homem atual e de todas as épocas e culturas. Trata-se de uma natureza humana. Mas essa natureza nada tem a ver com uma essência imutável e denota apenas o que todas as culturas da espécie Homo sapiens têm em comum.

Muitos artigos e inúmeros livros tratando da psicologia evolutiva já foram publicados. Alguns dos trabalhos mais representativos da psicologia evolutiva estão traduzidos para o português por editoras brasileiras (Pinker, 1998; Ridley, 2000; Miller, 2000; Wright, 2000, 1996). Esses autores nos mostram como os estudos sobre a cognição, baseados especialmente na psicologia cognitiva de um lado, e na biologia evolutiva do outro, se fundiram para originar uma abordagem evolutiva das mentes e sociedades humanas. Interpretando o cérebro como um computador (um achado da psicologia cognitiva), como uma máquina de processar informações, os adeptos da psicologia evolutiva consideram que a mente humana teria sido modelada para viver no inóspito ambiente de savana em que a espécie Homo sapiens emergiu. Para compreender o homem em sociedade e seus problemas, seria fundamental reconstruir um quadro histórico das forças mentais que impeliram o homem ao que ele é hoje. Esse quadro não poderia ser equacionado sem referência a ciências como a biologia evolutiva, significando que a biologia é necessária mas não suficiente para compreender os homens, suas mentes, sociedades e história em toda sua riqueza, complexidade e contradições.

A psicologia evolutiva é um afastamento da visão dominante da mente humana na tradição intelectual do Ocidente. John Tooby e Leda Cosmide batizaram essa tradição como Modelo Clássico das Ciências Sociais (MCCS, ou, em inglês, Standard Social Science Model, SSSM). O MCCS postula uma divisão fundamental entre biologia e cultura A biologia dota os seres humanos com os cinco sentidos, 
alguns impulsos como a fome e o medo e uma capacidade geral para o aprendizado (Tooby \& Cosmides, 1992; Pinker, 1998). O cérebro é compreendido como um aparato de resolução geral de problemas sem áreas ou regiões especializadas. A evolução biológica, segundo os adeptos de um MCCS, tem sido suplantada pela evolução cultural. Um dos elementos mais importantes da revolução que a psicologia evolutiva trouxe foi, aprofundando achados da sociobiologia, a consideração de que o cérebro e a mente são modulares. Para evitar predadores, comer o alimento certo, formar alianças e amizades, prover ajuda aos filhos e outros parentes, ler as mentes alheias, comunicar-se com outras pessoas e selecionar parceiros sociais, a seleção natural desenvolveu módulos específicos. Tooby e Cosmides conjecturam que o cérebro humano poderia ter cerca de mil módulos diferentes. O que chamamos de cultura poderia ser interpretado como um caminho instintivo aberto pelos módulos do cérebro com o intuito de tirar vantagens do ambiente a partir da experiência, explorando ontogenética e filogeneticamente o arcabouço físico que a vida nos ofertou.

Uma das tentativas mais conhecidas desse tipo de abordagem se encontra na obra $O$ animal moral, de Robert Wright. Partindo das bases biogenéticas do comportamento humano, Wright reinterpreta o caráter de Charles Darwin à luz da psicologia evolutiva. Reconstruindo a moral vitoriana do pai do evolucionismo moderno, Wright mostra como Darwin foi movido por motivos científicos e ao mesmo tempo por desejos irracionais de projeção profissional e auto-afirmação pessoal. Tais desejos seriam irracionais, na medida em que estudos de inúmeras culturas humanas e protoculturas não humanas conseguem demonstrar certa concordância entre $o$ comportamento humano e o de outros animais. Todos estamos, aos olhos da biologia evolutiva, sujeitos a um jogo irracional de interesses, de conflitos, alianças e traições. Penso por exemplo, no livro de Jane Goodall, Uma janela para a vida: 30 anos com os chimpanzés da Tanzânia. Os relatos ali contidos revelam uma realidade que deixou perplexo até mesmo o mundo científico. As semelhanças dos chimpanzés com o homem não se limitam à estrutura molecular do DNA. Os chimpanzés também têm história, com alianças familiares e desenvolvimentos de dinastias, guerras tribais, ascensão e queda de líderes, epidemias e até episódios de infanticídio e canibalismo.

A aspiração de Darwin em ser (bem) considerado por seus pares científicos a partir de sua teoria está radicada não em uma sociedade específica, mas no impulso irracional que várias espécies animais exibem para maximizar vantagens sociais. $O$ conflito entre esse impulso natural e as regras sociais vitorianas torna o autor de Origem das espécies um caso particularmente rico, pois revela explicitamente o choque entre o 'ser' e o 'dever ser', entre a natureza e a cultura. Nem herói, nem vilão, nem santo, nem capelão do demô- 
nio, Darwin é mostrado com as cores mais contraditórias. Ele é visto quase como um grande primata que aprendeu regras de civilização, mas que mal pôde se acomodar dentro de seus angustiantes limites. A questão é que, segundo os adeptos da psicologia evolutiva, tudo indica que nós, assim como a sociedade em que vivemos, somos um resultado parcial e aberto de um processo de mudanças aleatórias e retenções seletivas que vêm se acumulando por centenas e centenas de milhões de anos. Provavelmente muitas rupturas aconteceram nesse processo. Em primeiro lugar, para o que estamos discutindo, a evolução biológica e o estado atual do homem e da sociedade não são a mesma coisa. Para que o homem apareça na história da vida é preciso que haja a tal evolução por seleção natural. Mas o contrário não é verdadeiro. A evolução prescinde do homem (já o 'conhecimento' de que a evolução ocorre provavelmente é um assunto apenas humano). $\mathrm{O}$ homem é um produto (parcial, como todo ser vivo) da evolução, e não o contrário.

Um corte decisivo na narrativa sobre a evolução em geral e a evolução humana em particular ocorreu em 1966, com a publicação de Adaptation and natural selection, de George C. Williams, ainda sem tradução no Brasil. Esse livro mostra que a evolução dos seres vivos deve ser contada principalmente como a história de entidades conhecidas como genes. Isso não significa que as dimensões do indivíduo e do grupo, em que anteriormente se baseava a tentativa de explicação, devam ser descuradas. Todavia, a descoberta das partículas responsáveis pela transmissão da informação hereditária de pais para filhos modificou completamente o modo de ver as coisas. Sobretudo porque alguns dos traços que nos caracterizam como humanos perante os outros seres vivos - o andar bípede, o cérebro grande em relação ao corpo - podem envolver e provavelmente envolvem mutações genéticas (que por sua vez devem ter acompanhado modificações nas condições de vida dos primatas pré-humanos que nos deram origem). ${ }^{4}$

Cérebros grandes não surgem por acaso, de uma hora para outra. Também não devem ser vistos como o produto de uma necessidade continuada da espécie, no sentido de que nossos ancestrais necessitaram de um cérebro grande para sobreviver. Provavelmente a inflação do cérebro (Dawkins, 2000), que parece ter cessado há uns cem ou duzentos mil anos, foi um produto de variações aleatórias no tamanho da caixa craniana e retenções seletivas favorecendo indivíduos que fossem portadores do referido aumento. Mas, afinal, por que os seres humanos têm um cérebro tão grande? Segundo os psicólogos evolutivos, tal tamanho não pode ser explicado em meros termos de uma luta pela sobrevivência darwiniana. Poderíamos sobreviver largamente com cérebros relativamente menores, como muitos outros primatas. Talvez não em sociedades tão complexas e estratificadas como as nossas, 
é claro. No entanto, não se deve pensar que as pressões das sociedades modernas tenham sido responsáveis por esse crescimento do cérebro, já que tais sociedades são produtos históricos relativamente recentes, e o cérebro humano teria inflado, não de um modo continuamente linear, desde cinco ou sete milhões de anos atrás até os já referidos cem ou duzentos mil anos antes de nós. As teorias apontam, então, para um mosaico de fatores que estabelecem uma relação em espiral, de feedback positivo, com o crescimento do cérebro: o bipedismo, a manufatura de implementos cada vez mais sofisticados, o domínio do fogo, o início do hábito de comer carne, a socialização necessária para a caça, para a coleta e para a partilha (observada em várias espécies animais): todos esses e outros processos devem ter contribuído para a evolução do cérebro e a origem da linguagem articulada. Uma abordagem ainda mais recente insiste em que a luta pela sobrevivência não pode ter influenciado a evolução da mente, mas que a seleção sexual teria força suficiente para fazêlo. Alguns autores nos últimos anos têm revivido o debate entre Darwin e Wallace a respeito da importância da seleção sexual (Cronin, 1995). Um deles é Geoffrey Miller. Ele argumenta que a seleção sexual não é apenas um caso especial de seleção natural, mas um processo autônomo em relação à luta direta pela existência. Assim, por exemplo, compor poemas e sinfonias não contribui em nada na luta pela existência em que vivem seus autores, assim como a cauda do pavão também não contribui diretamente para sua existência. Mas contribuiu, sim, na luta para achar um parceiro reprodutivo. A mente humana, segundo Miller, teria sido modelada pela seleção sexual. No caso, machos e fêmeas teriam desenvolvido, no decorrer da história evolutiva, uma preferência por indivíduos com cérebros ligeiramente maiores (Miller, 2000).

Em 1976, o zoólogo Richard Dawkins publicou o controvertido livro de divulgação científica, $O$ gene egoísta, no qual expôs com detalhes a revolucionária teoria de George $\mathrm{C}$. Williams: o nível mais importante e fundamental em que a seleção natural opera é o nível dos genes. Isso significa que a seleção natural favorece genes muitas vezes em detrimento dos indivíduos constituídos por eles. Embora atue diretamente sobre os indivíduos, eliminando-os ou preservando-os, a seleção natural favorece igualmente os genes que esses indivíduos carregam. O egoísmo no nível dos genes traduzse como a 'tendência' natural da vida em preservar e passar adiante genes que, orquestrados em indivíduos (em genótipos expressos em fenótipos) garantam uma certa aptidão, necessária para enfrentar os desafios da própria vida. A vida social do ancestral humano seria guiada pela lógica biológica de indivíduos lutando para passarem seus genes adiante.

Darwin, sem conhecer os genes, compreendeu o profundo significado do individualismo inerente à luta pela sobrevivência. Mas ele 
também já sabia da existência de comportamentos animais que poderiam ser interpretados, e foram, como instâncias críticas da teoria da seleção natural. O Capítulo VII da primeira edição de Origem das espécies é intitulado "Instintos". Nele, o autor continua apresentando as dificuldades da teoria da seleção natural, que havia esboçado no capítulo anterior. Agora ele discute a especificidade dos instintos das formigas neutras ou estéreis. Darwin parece estar ciente de que indivíduos que são estéreis não podem evoluir por seleção natural, porque é apenas através da reprodução que as características hereditárias podem evoluir.

O caso dos insetos neutros, deixou escrito o próprio Darwin, "a princípio me pareceu insuperável, senão mesmo fatal à minha teoria" (1985, p. 202). Por definição, indivíduos estéreis "não têm condição de propagar seu tipo" (p. 203). Darwin afirma que tal assunto merecia ser discutido amplamente, mas trata especificamente apenas do caso das estéreis operárias do formigueiro, apresentando várias dificuldades para a teoria da seleção natural. O altruísmo e o cooperativismo não poderiam ser explicados pela lógica da seleção natural, pois essa tende a preservar 'indivíduos' que melhor conseguem maximizar seus benefícios, principalmente nas espécies com reprodução sexuada, sobretudo na obtenção de parceiros para a geração da prole. Cabia mal dentro da lógica de Darwin o comportamento assexuado das formigas operárias e de outros insetos sociais: batalhões de indivíduos abrindo mão de sua reprodução, de sua chance de ter filhotes, de passar seus genes para as futuras gerações, e em vez disso, fazendo toda uma sorte de tarefas que culminavam na reprodução da rainha: ou seja, no caso específico das formigas, as operárias trabalham para cultivar irmãs - e não filhos, como nós humanos (Cronin, 1995).

Darwin responde a essas dificuldades dizendo que se tais animais vivessem em comunidades, e se para uma comunidade fosse proveitoso que um certo número de seus indivíduos apresentassem as características de operosidade e esterilidade, ele não veria grandes dificuldades para que a seleção natural atuasse no sentido de que, anualmente, nascessem tantos indivíduos quantos necessários àquela comunidade. Mas para ele a explicação difícil reside na diferença estrutural e de instintos tanto entre os machos como entre as fêmeas desses insetos sociais. A solução, mais uma vez, seria a de que a seleção pode atuar individual ou comunitariamente, desde que se atinja o fim almejado, no caso o bem da comunidade (cf. Darwin, 1985, p. 203-4; Cronin, 1995, p. 408-10).

Até meados da década de 1960 esse tipo de explicação baseada na seleção de grupo era bastante empregado. Um de seus representantes mais ilustres foi Mayne-Edwards (Cronin, 1995; Ridley, 1995; Dawkins, 1979). Nos marcos dessa teoria o comportamento altruísta era explicado pelas vantagens que gerava para o grupo, e 
não para os indivíduos. Um animal pode ser visto colocando em risco sua própria vida, ou diminuindo seus ganhos, para o bem da espécie. A espécie seria como que um superorganismo que possuiria mecanismos para que os indivíduos que a compõem se comportassem contrariando seus próprios interesses individuais para maximizar benefícios ao grupo ou à espécie. Ou seja, a seleção natural favoreceria os grupos em que os indivíduos estariam dispostos a se sacrificar para o bem da espécie, frente aos grupos em que os indivíduos não apresentassem traços desse comportamento (Dawkins, 1979). Entretanto, até hoje, não foi proposto nenhum mecanismo consistente para explicar como a espécie, o grupo e a comunidade podem controlar o destino dos indivíduos que os compõem.

Em muitas populações humanas e algumas não humanas existem exemplos claros de comportamentos cooperativos e altruístas. Estou argumentando que esses fatos não podem ser explicados pelo darwinismo de Darwin, a não ser que ele seja complementado pela síntese moderna e pelo trabalho de Williams e outros, que contradiz a importância da seleção de grupo. A teoria do gene egoísta explica os comportamentos altruísta e cooperativo como o resultado da seleção agindo no nível dos genes. Como os comportamentos não egoístas, a princípio, são observáveis sobretudo entre parentes muito próximos, pode-se demonstrar que é a lógica dos genes que está em jogo. Quando um indivíduo busca a todo preço proteger sua prole o que ele está fazendo é defender as cópias dos seus genes que estão representadas na própria prole. A esse tipo de comportamento deu-se o nome de seleção de parentesco ou aptidão inclusiva. Dentro desse enfoque, por exemplo, Daly e Wilson (2000, p. 52-3) interpretam que os índices de infanticídio são maiores entre filhos adotados do que entre os naturais, pois os pais verdadeiros tendem a injuriar menos fatalmente os genes presentes nos corpos dos próprios filhos (que afinal são cópias dos genes dos pais).

Mas observamos também na natureza e em sociedade indivíduos que, embora não sendo parentes, cooperam para um objetivo comum (altruísmo recíproco). E o caso de várias espécies de lobos e raposas que caçam em grupo animais de grande porte, algo que não poderiam fazer individualmente. Dividem-se nesse caso os custos e os benefícios (Zywicki, 2000). O livro Não-zero: a lógica do destino humano, de Robert Wright, mesmo autor de $O$ animal moral, busca aplicar a teoria dos jogos para estudar a origem, o desenvolvimento e o futuro das sociedades humanas, tendo como fundo a idéia de que a competição é uma causa tão poderosa da evolução biológica, cultural e humana, como a cooperação. Dentro do escopo da teoria dos jogos distinguem-se dois tipos de jogos: os jogos de soma zero e os jogos de soma não-zero. Os jogos de soma zero são aqueles como os de futebol ou de basquete, em que uma equipe (ou um indivíduo) deve ganhar 
e a outra necessariamente perder. Mas existem jogos em que os jogadores e ou equipes não desempenham um 'contra' o outro, mas jogam juntos, uns 'com' os outros, com vistas a maximizar seus benefícios ou minimizar suas perdas.

A teoria dos jogos é uma das contribuições mais importantes para a biologia evolutiva, pois foi capaz de oferecer um tratamento racional e lógico para o conflito de interesses que pode existir entre dois indivíduos biológicos que compartilham objetivos. $\mathrm{O}$ exemplo clássico é o de machos e fêmeas, que, em todas as espécies sexuadas, compartilham o interesse pela reprodução e pela prole, pois trata-se das chances de deixar seus respectivos genes para a posteridade. Só que cada indivíduo do par contribui diferentemente para a produção da tão almejada prole. Em virtude da estrutura das populações naturais e do sistema sexual de muitas espécies, os interesses dos machos e das fêmeas, com vistas a maximizar suas taxas reprodutivas, não são idênticos (Ridley, 1995). Se olharmos espermatozóides e óvulos como os 'recursos' que cada indivíduo busca no sexo oposto, teremos de concordar que um óvulo é um bem muito mais valioso e limitado em relação às multidões já epigramáticas dos espermatozóides. A diferença de tamanho entre um minúsculo gameta masculino e um avantajado (em relação ao espermatozóide) óvulo é um símbolo da diferença no valor de mercado reprodutivo desses diferentes gametas. Isso significa que os machos tendem a abandonar a fêmea tão logo esteja garantida, de uma forma ou de outra, a transmissão dos seus genes. Isso pode ocorrer assim que a cópula se encerra, como por exemplo entre muitos insetos, ou depois de os filhotes terem chegado a um determinado estágio de desenvolvimento em que o macho já não é mais indispensável.

Ocorre que, dado o comportamento altruísta e cooperativo de muitos indivíduos, observa-se na natureza e em sociedades a existência de outros indivíduos, não tão altruístas ou cooperativos, que exploram, para benefício próprio, a tendência natural ao comportamento cooperativo. Em termos mais especificamente humanos isso significa que em toda situação em que eu e meu parceiro podemos cooperar um com outro, nunca sabemos 'com certeza' o que se passa na mente alheia: não sei com toda segurança se meu comportamento cooperativo vai ser correspondido pelo outro; ou se este irá se aproveitar da minha boa vontade e explorá-la em benefício próprio, aos meus custos. E dessa forma é justo que o meu parceiro pense de mim o mesmo que penso dele. Essa situação, modelar para o estudo biológico do comportamento egoísta e cooperativo, ficou conhecido como 'o dilema do prisioneiro'.

O dilema do prisioneiro, assim como algumas de suas variantes, é parte da estrutura teórica de um campo do conhecimento chamado teoria dos jogos. Essa abordagem nasceu na década de 
1950 com economistas e matemáticos, desejosos em compreender e tentar predizer o comportamento de parceiros econômicos, sobretudo em situações em que houvesse conflito de interesses (Mello, 1997; Davis, 1973; Wright, 2000). A abordagem então foi aplicada ao comportamento biológico de animais, sobretudo da mesma espécie, tanto o comportamento altruísta e cooperativo quanto o comportamento egoísta. $\mathrm{O}$ resultado foi uma das mais prolíficas modelações matemáticas para estudos comportamentais. Alguns autores, incluindo Richard Dawkins, conseguiram traduzir para uma linguagem não-científica o profundo significado de se compreender que vivemos em um mundo no qual o conflito de interesses está presente, e que a construção de uma possível solidariedade deve ser feita a despeito de nossos genes, contrariando seus interesses mais imediatos de serem passados adiante. ${ }^{5}$ Certa vez, no decorrer disso que hoje já se transformou em história da biologia, perguntaram ao biólogo Haldane se ele se sacrificaria por um irmão. Ao que ele teria respondido: "Não, por um irmão não. Mas por dois sim. Ou por oito primos" (Nesse \& Williams, 1997). Devemos considerar que a resposta desse cientista se deu em um contexto neodarwinista. Os seres vivos, de que trata a biologia, lutam para passar seus genes adiante, ou seja, para terem filhos e netos. Isso vale tanto para animais como para plantas, embora as plantas não tenham filhos, na acepção comum dessa palavra, mas considerando sem dúvida que elas se reproduzem das formas as mais variadas. Isso vale também para seres microscópicos que não precisam 'cruzar' para se reproduzir: eles também passam seus genes adiante. Em um nível bem material e concreto, a vida é transmitida por um processo natural no qual os genes contêm as instruções para formar proteínas e outras moléculas biológicas. Ocorre que nenhum indivíduo vive isoladamente, mas em um ambiente extremamente complexo. Também os genes estão mergulhados em um nutritivo caldo protéico localizado no interior dos núcleos das células. A expressão de cada um desses genes faz parte de um processo no qual os genes são apenas um dos quase inumeráveis fatores. Os genes são necessários mas não suficientes. Os genes, e não as proteínas, são replicadores. Isso significa que a informação básica para produzir uma proteína, e que é transmitida de geração a geração, está contida nos genes, e não nas próprias proteínas. ${ }^{6}$

Darwin assinalava que o conceito de ambiente devia ser entendido como o ambiente físico, por exemplo, de uma floresta onde vive uma espécie - seu regime de chuvas, a intensidade variável dos seus ventos, a radiação que recebe do sol e de outras fontes, a composição de seu solo etc. Mas, 'ambiente' devia ser compreendido também, ao mesmo tempo, como os inúmeros outros organismos da mesma espécie em questão, assim como incontáveis outros indivíduos de outras espécies, próximas e distantes, com os quais necessa- 
riamente dividimos e disputamos o ambiente, e sem os quais não estaríamos vivos. Assim sendo, cada indivíduo estabelece relações vitais com muitos seres vivos. E o altruísmo e a cooperação são observados ali mesmo no nível dos indivíduos, sobretudo os da mesma espécie: os pais se sacrificam pelos filhos, as operárias por sua rainha: esses são apenas os exemplos clássicos de comportamento não egoísta na natureza.

Apesar de a psicologia evolutiva ser um campo de pesquisa promissor, ela vem sendo criticada por superestimar a importância dos genes para explicar o comportamento não egoísta e a ação do homem nas sociedades modernas. O egoísmo no nível dos genes não pode ser extrapolado, dizem esses críticos, como uma explicação para o egoísmo psicológico, humano (Sober, 1994). Uma das linhas que essa crítica segue consiste em enfatizar que a psicologia evolutiva é uma forma de reducionismo e determinismo, pois procura reduzir o comportamento complexo do homem, e de muitos animais, ao comportamento de partículas moleculares irracionais, os genes (Rose \& Rose, 2000). Outros nomes que merecem destaque nessa resistência à invasão neodarwinista são os do paleontólogo Stephen J. Gould, do geneticista Richard Lewontin e do neurologista Steven Rose, para ficar entre os mais conhecidos (Gould \& Lewontin, 1979; Rose \& Rose, 2000). Gould, Lewontin e Rose criticam o adaptacionismo, a doutrina darwinista que, segundo eles, interpreta todo traço fenotípico como uma adaptação modelada pela seleção natural. Eles também criticam o neodarwinismo por seu caráter reducionista, ao querer radicar o comportamento social humano na dimensão dos genes. Não posso deixar de me colocar aqui do lado dos 'reducionistas', chamando a atenção para distinção feita por Dennett entre o reducionismo ganancioso e o reducionismo metodológico. Os adeptos do reducionismo metodológico concebem os fatores genéticos como importantes, mas não as únicas peças no esquema de explicação; os reducionistas gananciosos acreditam que devem reduzir toda explicação na biologia (e por extensão no comportamento animal) a explicações físicas (Dennett, 1998, p. 85-6).

No meu modo de ver, nenhum biólogo sério considera que os genes determinam o comportamento total, mas que o comportamento possui um componente genético fundamental (Mayr, 1998). A interação entre natureza e cultura, entre gene e meio ambiente (no caso as condições moleculares específicas do núcleo da célula onde se encontra o gene), é cada vez mais compreendida como um processo em que nenhuma das partes determina e complementa o outro ou o todo, mas no qual a relação é de implicação múltipla no curso do tempo (Ridley, 2003). A psicologia evolutiva desafia alguns importantes dogmas sociais e culturais por equacionar genes e comportamentos. Ela entra em conflito com certas filosofias 
socioconstrutivistas que negam que o homem, sua sociedade e cultura sejam um produto da evolução por seleção natural, pois as teorias não passam de construções sociais, assim como o comportamento humano em sociedades.

Uma outra linha crítica procura enfatizar que, embora as pesquisas da psicologia evolutiva sejam muito frutíferas, elas precisam ser complementadas por uma teoria que dê conta não só da evolução biológica do homem, mas também de sua evolução cultural. ${ }^{7}$ É essa a crítica que o programa de pesquisa dos memes procura realizar e que apresento a seguir.

\section{A memética}

Alguns evolucionistas, estudiosos dos liames entre biologia e cultura, assinalam que os psicólogos evolutivos superestimam a importância dos genes, descurando do significado que a informação cultural e social pode ter, até mesmo como pressão seletiva que teria contribuído para o crescimento evolutivo do cérebro. Nesse sentido o programa de pesquisa dos memes ou memética pretende ser uma crítica à psicologia evolutiva, uma tentativa de introduzir um segundo replicador no algoritmo da evolução por seleção natural (Dennett, 1998). Partindo da mesma idéia revolucionária de Williams, de 1966, Richard Dawkins, na conclusão de seu controvertido livro O gene egoísta escreveu que, após centenas de milhões de anos de domínio do gene como a única espécie de replicador natural, um segundo tipo de replicador não genético, cultural, teria emergido em meio a populações humanas e colonizado, como um vírus, os cérebros dos homens. Dawkins define o meme como

uma unidade de transmissão cultural, ou unidade de imitação. "Mimeme" vem da raiz grega adequada, mas quero um termo que soe mais como "gene" ... Também se pode pensar que ele está relacionado com "memória" ou com a palavra même, do francês...

Exemplos de memes são melodias, idéias, expressões, estilos de roupa, maneiras de fazer potes ou construir arcos. Assim como os genes se propagavam no pool gênico saltando de corpo em corpo via espermas ou óvulos, os memes se propagam no pool memético saltando de cérebro em cérebro por um processo que, no sentido mais amplo, pode ser chamado de imitação. Se um cientista ouve falar ou lê a respeito de uma idéia, ele a transmite para seus colegas e alunos. Ele a menciona em seus artigos e palestras. Se a idéia for bem sucedida, pode-se dizer que ela se propaga, espalhando-se de cérebro em cérebro. (Dawkins, 1979, p. 214)

Desde então a idéia de se pesquisar a cultura como um complexo caldo no qual inúmeros memes, fragmentos de memes e complexos 
de memes são passados adiante, de homem a homem, de geração a geração por um mecanismo de 'imitação', ganhou força e profundidade. Não existem ainda mais que uma dúzia de obras dedicadas inteiramente ao assunto. Algumas das mais importantes são: Virus of the mind, de Richard Brodie (1996); Thought contagion, de Aaron Lynch (1996); The meme machine, de Susan Blackmore (1999); The imitation factor, de Dugatkin (2000); a coletânea de artigos Darwinizing culture: the status of memetics as a science, que tem Robert Aunger como editor (2001), e The electric meme, do mesmo Aunger (2002). Não existe nenhuma tradução desses trabalhos para o português. Embora o número de livros seja pequeno, o mesmo não se pode dizer sobre o volume de artigos sobre o tema. Revistas especializadas como Biology and Philosophy e de divulgação como a Scientific American já publicaram papers sobre esse tema (Wimsatt, 1999; Blackmore, 2000). Além disso, existem sites na Internet dedicados ao assunto, tendo o programa de pesquisa sobre os memes uma publicação eletrônica própria, o Journal in memetic research, em que se encontram inúmeros artigos sobre os memes e links para outros sites (ver bibliografia).

Para Susan Blackmore, autora de The meme machine, memes são "instruções para realizar comportamentos, estocadas no cérebro (ou em outros objetos), e passadas adiante por imitação" (Blackmore, 1999 , p. 43). Na verdade, segundo a autora, nós, seres humanos, e nossos cérebros somos máquinas de reprodução de idéias. Enfatizo que o mecanismo básico pelo qual uma idéia é reproduzida é a 'imitação', e que os genes estão para os corpos como os memes para os cérebros humanos.

Dawkins foi o primeiro a nomear os 'memes' em 1976, mas Hull, em 2000, afirma que a memética teria no máximo doze anos, indicando que Dawkins não é em absoluto o autor a interpretar e aplicar seriamente a idéia de meme como um ponto de partida para um programa de pesquisa ou uma tradição de investigação. Em 1995, no livro A perigosa idéia de Darwin, publicado no Brasil em 1998, o filósofo da mente D. C. Dennett dedica um capítulo inteiro aos memes, para tratar do cérebro como ninho de memes. Além desse capítulo, o livro está coalhado de referências aos memes, em vários contextos, e indica uma linha de raciocínio consistente em defesa da aproximação entre a filosofia e as ciências humanas, de um lado, e o darwinismo, do outro (Dennett, 1998; Runciman, 1998).

Qual é a natureza da informação biológica? Qual é a natureza da informação cultural? Subjacente aos fenômenos da evolução biológica e da evolução cultural reside o processo que conhecemos pelo nome de linguagem. Embora seja impossível superestimar a importância da linguagem entre os homens e também entre outros animais sociais, a linguagem é um fenômeno cuja definição, talvez, não seja tão problemática. Porém, a definição de informação é extremamente problemática (Hull, 2001), não por pobreza semântica 
mas pela sua sobredeterminação. $O$ mesmo ocorreria com o conceito de aprendizagem (Tooby \& Cosmides, 1992). A informação contida nos genes está codificada em uma linguagem química. Mesmo a definição de gene também pode assumir vários sentidos (Ridley, 2003), alguns deles certamente problemáticos entre si; mas nenhum geneticista se paralisa por causa dessas dificuldades. Como salientou Popper, a ciência não lida com o aperfeiçoamento de definições, mas com a eliminação de erros. Para a memética, cérebros (mentes), genes e memes interagem. E interagem com outras estruturas e superestruturas como prédios, instituições, comunidades que não podem ser reduzidas a genes e/ou idéias sem uma perda brutal de informações.

É importante esclarecer que o quadro aqui descrito não representa uma posição inventada ou descoberta por Dawkins, pois muitas pessoas parecem crer que ele é o personagem principal de uma mudança na forma de pensar respostas para os problemas do altruísmo e do cooperativismo. Em realidade O gene egoísta é talvez a primeira tentativa de apresentar em termos não técnicos uma mudança de paradigma ocorrida dentro da Teoria Sintética da Evolução e que veio a dar origem ao conceito evolutivo de gene (Ridley, 2003). George Williams, William Hamilton, Robert Trivers e John Maynard-Smith, entre outros, contribuíram para construir a idéia de que o nível fundamental em que a seleção natural opera é do gene e não do indivíduo, ou do grupo, ou ainda da espécie (Dennett, 1998; Ridley, 1995, 2003). Assim, vimos que um dos grandes avanços da biologia evolutiva nos meados da década de 1960 foi interpretar o comportamento cooperativo ou altruísta segundo o ponto de vista dos genes. Na média, uma fêmea de uma espécie qualquer, do ponto de vista dos genes, não pode abandonar sua prole enquanto ela a carrega em seu ventre, coisa que o macho pode obviamente fazer. $\mathrm{O}$ que estamos querendo assinalar é que, biologicamente, devemos considerar qualquer comportamento cooperativo ou egoísta não só no nível dos indivíduos, e muito menos apenas no dos grupos. Mas principalmente no nível dos genes.

Para Dawkins, genes e memes são replicadores; os corpos dos seres vivos e os cérebros humanos são seus respectivos veículos. David Hull considera que a idéia de veículo sugere um ente por demais passivo e propõe para seu lugar o conceito de 'interator' (Hull, 2001). Os corpos dos seres vivos são interatores e, como tais, podem se reproduzir, mas não se replicar. As células são interatores. Cromossomos são interatores. Os replicadores também são interatores, mas de uma classe especial. Eles fazem uma coisa além de interagir: são capazes de mediar a replicação de si mesmos. Acontece que historicamente os replicadores que conhecemos se encontram confinados em interatores (ou veículos, na terminologia de Dawkins). A biologia molecular pode investigar a interação entre 
interatores e replicadores, a relação entre um gene e uma proteína, entre um gene e o genoma em que se encontra, entre o genoma e o ambiente celular, entre genomas, entre genomas e células, tecidos, órgãos etc., entre genoma e desenvolvimento, entre genoma e comportamento, entre genoma e evolução. Uma das funções da memética seria a de investigar a interação dos memes (replicadores) com os interatores em que estão contidos.

Blackmore (1999), Dawkins (2000) e também Wright (2000) consideram o problema das relações entre genes e memes, e sobretudo sua evolução conjunta (co-evolução), como uma das questões mais importantes dentro do programa de pesquisa dos memes. Pois existem idéias que promovem a passagem dos genes adiante, assim como existem idéias que competem com a transmissão genética. Entre esses dois extremos pode haver uma gama de diferentes interações entre idéias e genes. Em um dos extremos, por exemplo, a idéia do celibato impede que os genes de seus adeptos sejam passados adiante. Nesse sentido, uma idéia pode ser considerada egoísta no mesmo sentido que um gene o seria. Ou seja, ela pode se disseminar a despeito dos interesses dos próprios sujeitos.

Em hipótese alguma desejo significar que os genes e os memes sejam agentes conscientes ou intencionais. O que se defende é que uma idéia tende a se disseminar se ela ganha adeptos e se estes passam a idéia adiante, independentemente de a idéia ser boa do ponto de vista do sujeito. Naturalmente, as idéias que trazem vantagens para os interatores que as contêm tendem a ser mantidas na população. Mas do ponto de vista das idéias, são elas que usam os sujeitos humanos para se multiplicarem, assim como os livros usam os cérebros humanos para dialogarem entre si, assim como uma galinha é um artifício que um ovo cria para produzir outros ovos. As idéias são como vírus, vírus da mente, e como tal poderiam ser objeto de uma ciência como a epidemiologia (Lynch, 1996).

Muitas abordagens diferentes têm sido tentadas nos últimos anos utilizando uma perspectiva memética. Sob essa perspectiva, Gatherer fez uma revisão do estado da filosofia ocidental apontando certas áreas nas quais as escolas Européia e Anglo-Saxônica poderiam ser reconciliadas pelo uso de uma abordagem memética. Primeiramente, esse autor enfatiza as similaridades entre a classificação hierárquica dos habitantes do mundo ${ }^{8}$ de Karl Popper e a natureza hierárquica da analogia gene/meme (filogeneticamente, os genes antecedem os memes). Gatherer também compara o estudo dos memes com o das escolas de evolução cultural oriundas da antropologia social. Gatherer afirma que idéias incipientes muito semelhantes aos memes podem ser detectadas nos trabalhos de Charles S. Peirce, Ferdinand de Saussure, Ludwig Wittgenstein, Arnold Tonybee, Michel Foucault e Jacques Derrida. A principal conclusão a que Gatherer chega é que uma vez que a filosofia se preocupe com entidades de 
linguagem, 'informacionais', uma abordagem memética pode ser aplicada com proveito. Ele defende que tanto os interesses em matérias culturais da tradição Européia, quanto os interesses lógico e lingüístico da tradição Anglo-Saxônica podem ser expressos memeticamente.

Em uma linha de pensamento memético bem distinta Paul Marsden se pergunta se o suicídio pode ser um fenômeno social contagioso. Como se sabe, Émile Durkheim, um dos pais da sociologia, escreveu no final do século XIX um livro sobre o suicídio, e desde então apareceram inúmeras interpretações novas e debates sobre o assunto. No texto de Marsden o fenômeno do suicídio por contágio é demonstrado experimentalmente. Uma interpretação dos resultados é proposta usando um entendimento da memética como uma psicologia do contágio informada por um pensamento selecionista (de populações). Usando o termo 'meme' para denotar um objeto de contágio e 'contágio' para designar um processo de dispersão do meme por exposição a ele, Marsden fornece uma explicação selecionista do suicídio por influência de outros sujeitos. Sucintamente, Marsden argumenta que pessoas que se tornaram socialmente isoladas e privadas de direitos e bens culturais podem estar em risco particular de cometer suicídio, por exemplo, por ter ouvido informações sobre outros casos de suicídio. Marsdem sugere então, de forma breve, as importantes implicações para políticas de saúde pública de um entendimento memético do suicídio.

Já o médico Stephen Ross discute a hipótese de que algumas ou muitas doenças possam ser causadas por idéias, que os memes podem estar em cena no caso de certas manifestações mal-adaptativas. Por exemplo, ele argumenta que certas desordens alimentares podem ser contagiosas não por serem mediadas por qualquer patógeno clássico (microrganismos ou toxinas), mas, ao contrário, podem ser vistas como uma espécie de script socialmente construído, como no caso de anorexia nervosa ou de bulimia, transmitidas pela informação de que outras pessoas são afetas por essas doenças. Fibromialgias, síndromes de fadiga crônica, síndrome do intestino irritável e alcoolismo, assim como 'doenças psicogênicas de massa' ou histeria epidêmica podem ser interpretadas, em certos casos, como memes psicossomáticos. Nesse contexto, os memes são analisados como agentes infecciosos que, como os patógenos clássicos, possuem fatores de virulência, afetando hospedeiros particularmente vulneráveis. Essas idéias seriam disseminadas por uma variedade de vetores e promovidas ou inibidas por vários componentes da ecologia social.

Por sua vez, Mario Vaneechoutte e John Skoyles sugerem que a linguagem falada tem uma origem memética e que nós humanos somos uma espécie de primatas musicais. Segundo esses autores as canções (a musicalidade, a capacidade de cantar) estariam na base da origem evolutiva da fala humana e do desenvolvimento da fala 
durante a primeira infância. Contrapondo-se a Steven Pinker, Vaneechoutte e Skoyles sugerem que a linguagem humana teria surgido da combinação de três fatores: 1) seleção natural durante a evolução animal para uma crescente habilidade de representação mental; 2) seleção natural para a habilidade de cantar na evolução recente do homem; e 3) seleção memética ainda mais recente (últimos cem mil anos) para reusar as habilidades evoluídas prévias. Nesse contexto a fala (speech, no original) - o uso de sons simbólicos ligados gramaticalmente - seria interpretada como um fenômeno cultural, ligada à revolução do paleolítico superior (ocorrida há quarenta mil anos). A habilidade de cantar teria provido um aparato físico e o controle neural da respiração que é usado quando falamos (ou cantamos). A habilidade de cantar teria evoluído em outros grupos animais, como o dos babuínos, o das baleias e o das aves canoras, embora nessas espécies não tenha havido a transição do canto para a fala.

A esta altura, não se pode deixar de indicar que a teoria dos memes tem recebido muitas críticas. De um modo mais geral, tal teoria supostamente atomizaria o comportamento humano, sugerindo que as idéias têm intenções e vidas próprias (Miedgley, 2000). Segundo tal crítica, o programa dos memes nada mais faz que imitar ou reproduzir o padrão básico da ciência ocidental como um todo, em sua tendência e pretensão de dominar a natureza e o comportamento humano (Rose \& Rose, 2000). De uma maneira mais específica, a ciência dos memes reduziria fenômenos culturais e sociais complexos em partes mais simples, os memes, acreditando que ao explicar os níveis mais simples quedariam compreendidos também os níveis superiores. Miedgley quer mostrar que o programa dos memes pretende reduzir o comportamento de mulheres e de homens a respostas robóticas a uma invasão de memes (e genes).

A meu ver, uma crítica das mais importante pode ser encontrada no artigo de Wimsatt (1999). Nesse ensaio ele admite a existência de importantes unidades de imitação cultural. Wimsatt considera que a analogia com os genes, se for para ser tratada seriamente, precisa levar em conta certas dificuldades, por exemplo, as importantes diferenças entre as naturezas da informação genética e memética. Os genes se encontram em uma molécula química, o DNA. Os memes, as idéias, não se encontram em molécula biológica nenhuma. Não existem moléculas culturais. A replicação do DNA tende a excluir os erros de cópia que porventura ocorram durante o processo de replicação da informação genética. As idéias tendem a ser, ao contrário, pouco resistentes a quaisquer adendos. Isso dificultaria a ação de processos seletivos sobre os memes. Para que a seleção possa atuar as unidades de seleção devem ser apreciavelmente imunes a pressões ambientais imediatas, e principalmente dirigidas a um fim, pois, a princípio, uma herança de caracteres 
adquiridos adulteraria ou anularia o trabalho cumulativo da seleção. Portanto, se o mecanismo pelo qual herdamos informações culturais for o da herança dos caracteres adquiridos, a teoria dos memes, baseada no paradigma darwinista, estaria em sérias dificuldades.

Todavia, essas críticas podem ser contornadas. Em primeiro lugar, a linguagem como um veículo de idéias pode ser compreendido como a 'molécula' da informação cultural. Embora a linguagem não possua uma base física como possui o DNA, não se pode pensar a informação cultural sem um tipo qualquer de linguagem. Em segundo lugar, embora as idéias possam evoluir por mecanismos de herança de características adquiridas, elas possuem a característica de parecerem desenhadas para determinados fins. Se migrarmos por um instante, do campo geral das idéias para a filosofia da ciência, poderemos pensar que as idéias são como os programas de pesquisa de Lakatos. Para esse filósofo, o que chamamos de teoria científica é uma complexa estrutura de linguagem constituída por um núcleo e um cinturão protetor. O cinturão é composto por proposições que podem ser desafiadas e até refutadas pela evidência empírica sem que isso implique prejuízo para o núcleo e para o programa como um todo. O núcleo seria composto por proposições que só seriam refutadas em momentos verdadeiramente revolucionários (Lakatos, 1970). A analogia entre as idéias e os programas de pesquisa permite ver que as primeiras podem também possuir um núcleo que é transmitido aproximadamente intacto de geração a geração. Pense na idéia de Deus, o quanto ela mudou e o quanto ela é a mesma. Pense na própria idéia do darwinismo no tempo de Darwin e na de hoje. Há alguma coisa que permanece entre as gerações de cientistas e que portanto pode estar sujeita à modelagem seletiva.

Há certamente muitos entraves importantes. Blackmore, por exemplo, interpreta o self como uma ilusão gerada pelos memes para reproduzir memes. Ao tentar conjugar tal interpretação com uma visão de mundo budista, dá margem para que especulações de ordem mais mística se insiram no debate (Blackmore, 1999). Mas o nosso trabalho aqui não é saber o que é o self, ou mesmo o que é o meme, o que é a cultura, o que é a vida. Embora as definições sejam elementos importantíssimos no conhecimento científico elas não são seu alvo principal (Popper, 1987; Waizbort, 2000). Queremos saber não a definição precisa de um ente, mas como se comportam os sujeitos, as idéias, os genes, a história, tanto para tentar elucidar o passado, como para quem sabe planejar um futuro menos perverso. Não queremos saber o que é o mundo ou mesmo a natureza mais fina do espaço e do tempo. Estamos tentando enfrentar problemas concretos, práticos e/ou teóricos. E um desses problemas, talvez não o menor deles, seja o de conhecer nossas origens, e se essas origens podem de alguma 
forma contribuir para compreender o estado atual em que estamos, e audaciosamente sugerir soluções.

Talvez seja realmente isto o que buscamos: sermos donos de nós mesmos e de nosso futuro. Mas assim como nosso corpo envelhece, adoece e morre a despeito de nossa vontade, independentemente da cultura em que estamos, talvez precisássemos, para sermos verdadeiramente livres, reconhecer nossos próprios condicionamentos históricos. Mas isso significaria admitir que se não há mundo fora da linguagem, também não há mundo humano fora dessas unidades de imitação que chamamos idéias. Isso não significa que tudo são memes, e também não significa que tudo é linguagem. Ao contrário, a linguagem e as idéias, científica e epistemolo-gicamente, garantem seu poder explicativo a partir do reconhecimento da existência de outras entidades particulares no mundo. Assim, tanto em The meme machine quanto no artigo "The power of memes", Blackmore assinala enfaticamente que nem tudo são memes. Os genes e os corpos em que vivemos, nossas experiências subjetivas e emoções complexas, nossas percepções sensoriais, comer, respirar, fazer sexo, nossos mapas cognitivos, as associações que fazemos entre sons e cheiros, nada disso são memes; embora, para poder me referir a esses comportamentos, eu tenha feito uso naturalmente de uma linguagem e de idéias. Note-se que, além disso, muitos comportamentos humanos são uma complicada mistura do inato, do aprendido e do imitado - como por exemplo, dirigir um automóvel. Portanto, importa não hipostasiar o mundo dos memes dizendo que tudo são idéias, mas investigar como as idéias que recebemos sobretudo da família, das tradições, dos livros interagem com essa estrutura biológica, sensorial e motora, que herdamos de nossos pais e que provavelmente passaremos adiante, se tivermos filhos.

Mas então o que se ganha transformando as idéias em particulares tão importantes quanto os próprios sujeitos humanos? Em primeiro lugar, trata-se de uma tentativa científica de compreender a cultura e a história da humanidade de um ponto de vista evolutivo, darwinista. Busca-se nesse sentido um algoritmo que compreenda a evolução das idéias, um processo que notoriamente se desenvolve muito mais rápido que a evolução das espécies biológicas. Não se trata de reeditar com o par gene/meme as oposições entre nature e nurture, entre biologia e cultura, mas tentar interpretar, partindo de uma base evolutiva, o comportamento humano em sociedade e os problemas que se apresentam no estado atual da história. Isso só será conseguido, a meu ver, se compreendermos que tanto o gene como o meme são entidades históricas, que o desenvolvimento seja do corpo seja da mente é um processo de mão dupla, em que os replicadores interagem com níveis de organização inferiores e superiores e que dependem profundamente do contexto 
em que estão inseridos. A natureza humana, se há algum sentido em usar essa expressão, é o resultado provisório da interação de genes específicos com ambientes os mais variados. O denominador comum reside nessa estrutura de genes, proteínas e idéias que somos, nas mais variadas épocas e culturas. Nesse sentido a cultura e a civilização não enterraram de uma vez por todas a dinastia dos instintos em um antigo e bárbaro mundo animal, mas abriu um leque de inumeráveis possibilidades para o animal humano explorar.

A psicologia evolutiva e a memética procuram investigar o comportamento humano tendo como base a teoria neodarwinista. Todavia o neodarwinismo é um emaranhado tão complexo de evidências, conjecturas e argumentos que o leitor não especializado pode ficar rapidamente perdido. Tentemos esclarecer alguns pontos. Em primeiro lugar a teoria da evolução por seleção natural de Darwin não propõe, de forma alguma, que da luta pela sobrevivência sobrevenham inexoravelmente organismos ou nações superiores ou mais evoluídos, como defendia Herbert Spencer. Considerando a moderna teoria da evolução, devemos promover uma síntese entre a idéia de descendência com modificação mais seleção natural, de Darwin, e a idéia dos fatores hereditários discretos, descobertos por Gregor Mendel, e mais tarde batizados de genes. Sem dúvida, o 'comportamento' hereditário das ervilhas de Mendel só pode ser compreendido quando se reconhece a existência de 'átomos' hereditários, ou melhor, entidades biológicas, fatores físicos particularizados que 'causam' determinado traço fenotípico. É a partir daí que a teoria de Darwin encontra sua base genética, promovendo a referida síntese.

A psicologia evolutiva procura argumentar que os módulos cerebrais que possuiríamos hoje, sobretudo o que chamamos de mente, são um produto de milhões de anos de evolução genética do cérebro humano. O cérebro humano que criou o pensamento moral, filosófico e religioso, as artes incluindo a literatura e a música, as ciências e a matemática, seria um cérebro moldado para condições de vida que hoje já não existem mais. Vivemos em um mundo de cultura no qual a luta pela sobrevivência se viu atenuada, historicamente, pelas formas político-econômicas de enfrentar muitos problemas materiais, inclusive doenças e carências de alimento. Entretanto, nossos sentimentos morais, segundo os psicólogos evolutivos, ainda remontam àqueles de um tempo perdido, nada romântico ou hospitaleiro, no qual a comida não estava nas prateleiras e os rebentos menos viáveis eram abandonados à sua própria sorte.

Todavia, de um modo geral, os psicólogos evolutivos não consideram que a transmissão cultural da informação possa ter influenciado decisivamente o crescimento evolutivo do cérebro, sendo apenas um 
subproduto dessa evolução do cérebro. Essa é talvez a maior crítica do programa de pesquisa dos memes à psicologia evolutiva. É fato que alguns adeptos da psicologia evolutiva admitem os memes na estrutura explicativa de seus argumentos. É o caso, por exemplo, das breves referências de Miller em seu livro A mente seletiva. Assim, o estudo da interação entre genes e memes, natureza e cultura, constituição genética e ambiente, instinto e aprendizagem é de fundamental importância se o objetivo é compreender o comportamento humano de forma integrada e com mais dimensões.

\section{NOTAS}

${ }^{1}$ A história da genética entre Mendel e Watson/Crick, embora apresente muitas lacunas, como todo esforço histórico, é bastante desenvolvida e não é absolutamente linear, tendo evoluído em linhagens diferentes. Assim, a genética clássica de Mendel, a citogenética, a genética de populações, a genética molecular são ramificações com seus próprios personagens, experimentos, idéias e controvérsias (Mayr, 1998, Capítulo 17, p 811-865).

2 Darwin, em Origem das espécies, reconhece explicitamente a lamentável inexistência de uma teoria da hereditariedade convincente e consistente. Mais tarde ele próprio sugeriria uma teoria para tentar explicar como os caracteres físicos e comportamentais são transmitidos de geração a geração, a pangênese, que, cientificamente, não vingou.

${ }^{3}$ Para um panorama confiável e atualizado sobre o assunto remeto o leitor para o segundo número da Scientific American Brasil, ed. especial, de dezembro de 2003.

${ }^{4}$ Em meados de 2003 Matt Ridley publicou Nature via nurture, um livro que trata do conflito entre natureza e cultura a respeito da determinação do comportamento humano. Ridley acredita, como o autor destas linhas, que o gene sequer existe senão em um ambiente específico, vale dizer, necessariamente histórico. Como sublinha um outro filósofo da biologia, David Hull, as espécies de seres vivos são atores genealógicos em um palco ecológico. Só que, como ele sublinha, boa parte do que é um palco para uma espécie, é formada por outras espécies.

${ }^{5}$ Os genes não são entidades intencionais. Só entes que possuem uma mente podem ser intencionais. Os genes são regidos por uma lógica de replicação. Essa lógica pode simular a intencionalidade e o propósito. Tudo o que favorece a replicação dos genes é selecionado. Do ponto de vista do gene, certos traços fenotípicos podem ser favoráveis e ao mesmo tempo desfavoráveis aos seus portadores ou veículos.

${ }^{6}$ Nos últimos anos entidades moleculares chamadas príons foram descobertas, envolvidas com a doença da vaca louca e outras doenças neurodegenerativas. Os príons são uma classe especial de proteínas: eles são proteínas replicadoras. Eles são capazes de, quando em contato com proteínas normais, não replicadoras, mudarem apenas sua forma tridimensional, tornando-as replicadoras também (Aunger, 2002).

7 Como muitos sabem a origem e evolução das culturas humanas é por definição objeto da antropologia. Mas a própria definição de cultura é bastante problemática (Kuper, 2002; Geertz, 1978). Portanto, qualquer teoria sobre a cultura provinda da biologia ou de qualquer outra parte deve estar preparada para se ver sob o fogo crítico com que os antropólogos têm mantido o conceito de cultura.

8 Popper dá ao mundo físico o nome de 'mundo 1'; ao mundo das experiências subjetivas de cada sujeito chama 'mundo 2'. Além desses, ele reconhece um mundo dos conteúdos lógicos da linguagem, o qual denomina 'mundo $3^{\prime}$. Com tal classificação pretende distinguir entre um estado pessoal de veracidade (subjetivo) e a verdade de uma proposição (conteúdo lógico: objetivo). Nesse sentido, o mundo 3 seria o universo dos produtos lógicos da mente e da linguagem que possuem uma forma objetiva. Sobretudo os produtos das idéias que se tornaram públicos e foram fixados em bibliotecas, nos computadores, na mídia, fazendo parte desse universo que nem é simplesmente físico nem meramente um sonho do sujeito cognoscente (Popper, 1975, p. 152). 


\section{REFERÊNCIAS BIBLIOGRÁFICAS}

Aunger, Robert 2002

Aunger, Robert (ed.) 2001

Blackmore, Susan Oct. 2000

Blackmore, Susan 1999

Bowler, Peter 1989

Brodie, Richard 1996

Cronin, Helena 1995

Daly, Martin;

Wilson, Margo

Darwin, Charles 1985

Davis, Morton D. 1973

Dawkins, Richard 1979

Dawkins, Richard 2000

Dennett, Daniel C. 1998

Diamond, Jared 2001

Dugatkin, L. A. 2000

Evans, Dylan;

Zarate, Oscar 1999

Freitas, Renan Springer de 2000

Gatherer, Derek 1997

Geetrz, Clifford 1978

Goodall, Jane 1991

Gould, Stephen Jay; Lewontin, Richard 1997
The electric meme: a new theory of how we think.

New York: The Free Press.

Darwinizing culture: the status of memetics as a science.

Oxford: Oxford University Press.

The power of memes.

Scientific American, n. 283, p. 53-61.

The meme machine.

Oxford: Oxford University Press.

Evolution: a history of an idea. (rev. ed.)

Cambridge: University of California Press.

Virus of the mind: the new science of the meme.

Seattle (WA): Integral Press.

A formiga e o pavão: altruísmo e seleção sexual de Darwin até hoje. Campinas: Papirus.

La verdad sobre cenicienta: una aproximación darwiniana al amor parental. Barcelona: Ed. Crítica. 2000

Origem das espécies.

Belo Horizonte: Itatiaia, São Paulo: Edusp.

Teoria dos jogos: uma introdução não-técnica.

São Paulo: Cultrix.

O gene egoísta.

Belo Horizonte: Itatiaia, São Paulo: Edusp.

Desvendando o arco-íris: ciência, ilusão e encantamento.

São Paulo: Companhia da Letras.

A perigosa idéia de Darwin.

Rio de Janeiro: Rocco.

Armas, germes e aço: os destinos das sociedades humanas.

Rio de Janeiro: Record.

The imitation factor: evolution beyond the gene.

New York: The Free Press.

Introducing: evolutionary psychology.

Cambridge: Icon Books.

A desforra de Hume.

Revista Brasileira de Ciências Sociais, v. 15, n. 42, p. 23-38.

Macromemetics: towards a framework for the re-unification of

Philosophy. Journal of Memetics - Evolutionary Models of Information

Transmission, v. 1. Disponível em:

www.cpm.mmu.ac.uk/jom-emit/1997/vol1/gatherer_dg.html

A interpretação das culturas.

Rio de Janeiro: Zahar.

Uma janela para a vida: 30 anos com os chimpanzés da Tanzânia.

Rio de Janeiro: Zahar.

The spandrels of San Marco and the Panglosian paradigm: a critique of the adaptationist program. Proceedings of the Royal Society, v. B025, p. 591-8. 
Hull, David 2001

Kuper, Adam 2002

Lakatos, Imre 1970

Leis, Hector Ricardo 2000

Leakey, Richard 1995

Leakey, Richard;

Lewin, Roger

1987

Lynch, Aaron 1996

Marsden, Paul

Mayr, Ernst 1998

Mello, Flavia de Campos 1997

Miller, Geoffrey F. 2000

Miedgley, Mary 2000

Nesse, Randolph;

Williams, George C. 1997

Pinker, Steven 1998

Popper, Karl Raimund 1987

Popper, Karl Raimund 1975

Ridley, Matt 2003

Ridley, Matt 2000

Ridley, Matt 1995

Rose, Hilary;

Rose, Steven

Ross, Stephen E. 1999
Taking memetics seriously: Memetics will be what we make it. In: Aunger, Robert. Darwinizing Culture: the State of Memetics as a Science. Oxford: Oxford University Press, p. 43-67.

Cultura: a visão dos antropólogos.

Bauru: Edusc.

Falsification and the methodology of scientific research programmes. In: Lakatos, Imre \& Musgrave, Alan (ed.) Criticism and the growth of knowledge. Cambridge: Cambridge University Press, p. 91-196.

A tristeza de ser sociólogo no século XXI.

Dados, v. 43, n. 4, p. 737-60.

A origem da espécie humana.

Rio de Janeiro: Rocco.

O povo do lago.

Brasília: Ed.UnB, São Paulo: Melhoramentos.

Thought contagion: how belief spreads trough society.

New York: Basic Books.

Is Suicide Contagious? A case study in applied memetics. Journal of Memetics - Evolutionary Models of Information Transmission, v. 5. Disponível em: www.cpm.mmu.ac.uk/jom-emit/2001/vol5/marsden_p.html

O desenvolvimento do pensamento biológico.

Brasília: Ed. UnB.

Teoria dos jogos e relações internacionais: um balanço do debates. Revista Brasileira de Informação em Ciências Sociais, n. 44, p. 105-19.

A mente seletiva: como a escolha sexual influenciou a evolução da natureza humana. Rio de Janeiro: Campus.

Why memes? In: Rose, Hilary; Rose, Steven. Alas, poor Darwin: arguments against evolutionary psychology.

New York: Harmony Books, p. 79-99.

Por que adoecemos? A nova ciência da medicina darwinista.

Rio de Janeiro: Campus.

Como a mente funciona.

São Paulo: Companhia das Letras.

A sociedade aberta e seus inimigos.

Belo Horizonte: Itatiaia, São Paulo: Edusp.

Conhecimento objetivo: uma abordagem evolucionária.

Belo Horizonte: Itatiaia, São Paulo: Edusp.

Nature via nurture: genes, experience and waht makes us human. New York: Harper Colins Publisher.

As origens da virtude.

Trad. Berilo Vargas. Rio de Janeiro: Record.

The red queen: sex and the evolution of human nature.

New York: Penguin Books.

Alas, poor Darwin: arguments against evolutionary psychology.

New York: Harmony Books.2000

'Memes' as infectious agents in psychosomatic illness.

Annals of Internal Medicine, v. 131, n. 11. 
Runcinam, W. C.

Apr. 1998

Ruse, Michael

1983

Scientific American

Brasil

dez. 2003

Snow, Charles Percy 1995

Sober, Elliot 1994

Tooby, John;

Cosmides, Leda 1992

Vaneechoutte, Mario;

Waizbort, Ricardo 2000

Williams, George C. 1966

Wilson, Edward 1975

Wimsatt, W. C. 1999

Wright, Robert 2000

Wright, Robert 1996

Zywicki, Todd J. 2000
Soicalising Darwin.

Prospect.

Sociobiologia: senso ou contra-senso.

Belo Horizonte: Itatiaia, São Paulo: Edusp.

Novo olhar sobre a evolução humana.

(ed. especial, n. 2) São Paulo: Duetto.

As duas culturas e uma segunda leitura.

São Paulo: Edusp.

From a biological point of view: essays in evolutionary philosophy.

New York: Cambridge University Press.

The psychological foundations of culture. In: Barkow, J.; Cosmides, L.; Tooby, J. (org.) The adapted mind: evolutionary psychology and the generation of culture. New York: Oxford University Press, p. 19-136.

The memetic origin of language: modern humans as musical primates. Journal of Memetics - Evolutionary Models of Information Transmission, v. 2. Disponível em: jom-emit.cfpm.org/1998/vol2vaneechoutte_m\&skoyles_jr.html

Cento e quarenta anos sem Darwin bastam: sobre espécies variedades e definições. Principia, Florianópolis, v. 4, n. 1, p. 141-84.

Adaptation and natural selection.

Princeton: Princeton University Press.

Sociobiology: the new synthesis.

Cambridge (Mass): Harvard University Press.

Genes, memes and cultural heredity.

Biology and Philosophy, v. 14, p. 279-310.

Não-zero: a lógica do destino humano.

Rio de Janeiro: Campus.

O animal moral.

Rio de Janeiro: Campus.

Evolutionary biology and the social sciences.

Humane Studies Review, v. 13, n. 1, p. 34-57.

Disponível em: www.theihs.org/libertyguide/hsr/hsr.php/36.html

Recebido para publicação em junho de 2003.

Aprovado para publicação em maio de 2004. 